\title{
New solutions in grain protection against fusariosis
}

\section{Nowe rozwiązania w ochronie zbóż przed fuzariozami}

\author{
Weronika Walkowiak¹, Teresa Krzyśko-Łupicka²
}

\section{Summary}

Grain fusariosis are caused by phytopathogenic fungi from genus Fusarium, which due to their high pathogenic properties and toxicity contribute to enormous farming loses. In crop farming they lower grain harvests and worsen its quality, especially the ability to germinate and baking parameters. Most of the wheat diseases are caused by fungi from genera $F$. culmorum, F. graminearum, F. nivale, F. avenaceum, F. sporotrichioides, F. poae, F. oxysporum and F.verticillioides. Chemical fungicides are often used to control fusariosis, however, despite their effectiveness and easy application, they have not gained good recognition. Phytopathogenic fungi become resistant to fungicides, they reduce beneficial organisms and endanger the health of a consumer. It has led to a search of alternative methods of controling grain fusariosis, with the application of effective biodegradable fungicides and products containing active substances of natural origin or antagonistic microorganisms.

Key words: fusariosis; grain; fungicides; biofungicides; active substances

\section{Streszczenie}

Fuzariozy zbóż wywoływane są przez fitopatogenne grzyby strzępkowe rodzaju Fusarium, które przyczyniają się do strat gospodarczych, co wynika z ich patogenności i toksynotwórczości. W uprawach zbóż obniżają plon ziarna i pogorszają jego jakość, a zwłaszcza zdolność kiełkowania i parametry wypiekowe. Głównymi sprawcami chorób pszenicy są grzyby gatunków: $F$. culmorum, F. graminearum, F. nivale, F. avenaceum, F. sporotrichioides, F. poae, F. oxysporum i F. verticillioides. Do ich zwalczania stosuje się często chemiczne środki grzybobójcze, które mimo wysokiej skuteczności i łatwości stosowania nie cieszą się uznaniem, ze względu na zagrożenie bezpieczeństwa zdrowotnego konsumenta spowodowane pozostałościami fungicydów, zwiększającym się uodparnianiem patogenów i redukcją pożytecznych organizmów. Wszystko to sprawia, że poszukuje się alternatywnych metod ich zwalczania z zastosowaniem skutecznych biodegradowalnych fungicydów i preparatów zawierających w swym składzie substancje czynne pochodzenia naturalnego lub mikroorganizmy antagonistyczne.

Słowa kluczowe: fuzariozy; zboże; fungicydy; biofungicydy; substancje czynne

\footnotetext{
${ }^{1}$ Stypendystka projektu „Stypendia doktoranckie - Inwestycja w kadrę naukową województwa opolskiego” 


\section{Wstęp / Introduction}

Fuzariozy zbóż wywoływane są przez fitopatogenne grzyby strzępkowe rodzaju Fusarium, które porażają rośliny o podstawowym znaczeniu gospodarczym we wszystkich strefach klimatycznych, powodując znaczne straty plonów. Związane jest to $\mathrm{z}$ rozpowszechnieniem w środowisku, wysoką patogennością i toksynotwórczością tej grupy grzybów (Khan i wsp. 2006). Rozwój infekcji i jej zasięg w roślinie zależą od wielu czynników, m.in.: od zjadliwości patogena, ilości inokulum oraz odporności roślin, a zwłaszcza możliwości jej naturalnych mechanizmów obrony uwarunkowanej genetycznie. Porażenie roślin zależy od genów odporności występujących w genomie roślin, a szczególnie od genów wirulencji występujących u patogenów oraz (lub) od antagonistycznych oddziaływań mikroorganizmów ryzosferowych (Krzyśko-Łupicka 1993a, b, 2010, 2011) i wrażliwości patogenów na środki ochrony roślin (Krzyśko-Łupicka i Sudoł 2005, 2008). Wrażliwość roślin na porażenie przez Fusarium spp. może mieć pośredni wpływ na zwiększenie zachwaszczenia upraw. Znaczne obniżenie występowania fuzaryjnej zgorzeli podstawy źdźbła i korzeni pszenicy obserwowano po zastosowaniu podczas wegetacji roślin (w fazie pełnego krzewienia) herbicydów: Apyros $75 \mathrm{WG}$ + Atpolan, Affinity 50,75 WG oraz Attribut 70 WG (Narkiewicz-Jodko i wsp. 2005).

Patogeny należące do rodzaju Fusarium atakują rośliny we wszystkich fazach rozwoju, w pszenicy wywołują takie choroby, jak: przed- i powschodową zgorzel siewek, fuzaryjną zgorzel podstawy źdźbła i korzeni oraz fuzariozę kłosów (Nowak i wsp. 2005; Weber 2007). W uprawach zbóż, w zależności od fazy rozwoju zbóż, obniżają plon ziarna w zakresie 7-70\% (Korbas i Horoszkiewicz-Janka 2007) i pogarszają jego jakość, a zwłaszcza zdolność kiełkowania i parametry wypiekowe. Ziarna porażonego przez grzyby rodzaju Fusarium nie można wykorzystać jako materiał siewny ani do produkcji żywności czy paszy, ze względu na potencjalne zagrożenie mikotoksynami (Korbas 2005).

Głównymi sprawcami chorób pszenicy są grzyby gatunków: $F$. culmorum, $F$. graminearum, $F$. nivale, $F$. avenaceum, F. sporotrichioides, $F$. poae, $F$. oxysporum i $F$. verticillioides. $\mathrm{Na}$ terenie Polski dominują takie gatunki, jak: $F$. avenaceum, $F$. culmorum, $F$. graminearum, $F$. poae, $F$. oxysporum, $F$. nivale i $F$. solani (Kwaśna i wsp. 1991; Weber 2007). Do zwalczania tych polifagicznych grzybów zazwyczaj stosowane są fungicydy chemiczne takie, jak: Miedzian 50 WP (miedź), Amistar 250 SC (azoksystrobina i cyprokonazol), Tango Star 334 SE (fenpropimorf i epoksykonazol), Caramba 60 SL (metkonazol), Folicur Plus 375 EC (tebukonazol i triadimenol), Artea 330 EC (propikonazol i cyprokonazol), które mimo skuteczności i łatwości stosowania mogą stanowić zagrożenie bezpieczeństwa zdrowotnego konsumenta spowodowane ich pozostałościami oraz prowadzić do uodparniania patogenów grzybowych i redukcji pożytecznych organizmów (Nowak i wsp. 2005; Kordowska-Wiater 2011).

Problemy wynikające z patogenności i toksynotwórczości grzybów rodzaju Fusarium oraz nabywania oporności na stosowane fungicydy są jednymi $\mathrm{z}$ najważniejszych zagadnień rolnictwa, zarówno w krajach o niskim poziomie rolnictwa, jak również w krajach o nowoczesnym rolnictwie.

W trosce o naturalne środowisko, jak i skuteczna ochronę płodów rolnych prowadzone są wielokierunkowe badania, których celem jest przede wszystkim: eliminacja albo przynajmniej ograniczenie stosowania substancji chemicznych, na które fitopatogenne grzyby nabyły oporność (Sobiczewski 2010), poszukiwanie fungicydów skutecznych w niskich dawkach, nowych odpornych na infekcje odmian pszenicy i systemu upraw roli (Różalski i wsp. 1998; Małecka i wsp. 2001) oraz biologiczna ochrona roślin z wykorzystaniem biopreparatów. Biologiczna ochrona roślin przed chorobami obejmuje bardzo szeroką problematykę, w tym i wykorzystanie, tzw. naturalnej oporności gleb i podłoży, płodozmian, odpowiednie nawożenie, zastosowanie wyciąów z kompostu, roślin (olejki eteryczne i ekstrakty), zwierząt (chitozan), jak również żywych mikroorganizmów w zwalczaniu patogenów roślin.

\section{Nowe środki chemiczne / New chemical preparations}

Powszechnie obserwowane uodparnianie się grzybów rodzaju Fusarium na stosowane fungicydy (Sobiczewski 2010) zmusza do tworzenia nowych, skutecznie chroniących uprawy zbóż fungicydów. Szczególny nacisk położony jest na dobór substancji czynnych nowych fungicydów, które w niskich dawkach zapewnią skuteczną ochronę zbóż i pozwolą na uzyskanie ziarna o wysokiej zdrowotności. Najpowszechniej wykorzystywane w badaniach naukowych środki jako substancje czynne zawierają głównie triazole (np. metkonazol, tebukonazol, triadimenol), morfoliny (np. fenpropidyna, fenpropimorf), strobiluryny (np. pikoksystrobin), imidazole (np. prochloraz) lub mieszanki tych substancji (tab. 1).

Ocena skuteczności grzybobójczej różnych substancji czynnych fungicydów stosowanych do ochrony kłosa pod kątem uzyskania ziarna o wysokiej zdrowotności przeprowadzona $\mathrm{w}$ doświadczeniach poletkowych metoda sztucznej inokulacji kłosów pszenicy ozimej zawiesiną zarodników, np. F. culmorum wykazała, że skuteczną ochronę kłosa i wzrost plonu uzyskano po zastosowaniu mieszaniny związków triazoli - tebukonazolu i triadimenolu (Folicur Plus 375 EC) oraz triazolu i morfoliny epoksykonazolu i fenpropimorfu (Tango Star $334 \mathrm{SE}$ ) w dawkach zalecanych przez producenta. Jednak wyższą zdrowotność ziarna zapewniał fungicyd Folicur Plus 375 EC (tab. 1) zastosowany w dawce zalecanej przez producenta (Sikora i wsp. 2007). Z kolei Narkiewicz-Jodko i wsp. (2008) sugerują, że większy wpływ na cechy jakościowe i zdrowotność ziarna jęczmienia jarego miały warunki pogodowe panujące w latach zbioru niż testowane fungicydy. Prawdopodobnie trudność w ocenie skuteczności badanych fungicydów spowodowana była zbyt niskim stopniem porażenia rośliny przez patogenne grzyby rodzaju Fusarium (Narkiewicz-Jodko i wsp. 2008). 
Tabela 1. Fungicydy testowane w ochronie zbóż przed fitopatogennymi grzybami

Table 1. Fungicides tested in protection grain against phytopathogenic fungi

\begin{tabular}{|c|c|c|c|c|}
\hline $\begin{array}{l}\text { Fungicyd } \\
\text { Fungicide }\end{array}$ & $\begin{array}{l}\text { Substancja czynna } \\
\text { Active substance }\end{array}$ & $\begin{array}{c}\text { Grupa chemiczna } \\
\text { związków } \\
\text { Chemical group }\end{array}$ & $\begin{array}{c}\text { Dawki } \\
\text { Dosage } \\
{[1 / \mathrm{ha}]}\end{array}$ & $\begin{array}{l}\text { Literatura } \\
\text { Literature }\end{array}$ \\
\hline Caramba $60 \mathrm{SL}$ & metconazole & triazoles & 1,25 & $\begin{array}{l}\text { Sikora i wsp. (2007) } \\
\text { Narkiewicz-Jodko i wsp. (2008) }\end{array}$ \\
\hline Sportak 450 EC & prochloraz & imidazoles & 1,0 & Narkiewicz-Jodko i wsp. (2008) \\
\hline Tebu $250 \mathrm{EC}$ & \multirow{2}{*}{ tebuconazole } & \multirow{2}{*}{ triazoles } & \multirow{2}{*}{1,0} & \multirow{2}{*}{ Narkiewicz-Jodko i wsp. (2008) } \\
\hline Riza $250 \mathrm{EC}$ & & & & \\
\hline Cha 1876 & fenpropidin & morpholines & 1,0 & Narkiewicz-Jodko i wsp. (2008) \\
\hline Corbel $750 \mathrm{EC}$ & fenpropimorph & morpholines & 1,0 & Narkiewicz-Jodko i wsp. (2008) \\
\hline Folicur Plus 375 EC & tebuconazole + triadimenol & $\begin{array}{l}\text { triazoles } \\
+ \text { triazoles }\end{array}$ & 0,75 & $\begin{array}{l}\text { Sikora i wsp. (2007) } \\
\text { Narkiewicz-Jodko i wsp. (2008) }\end{array}$ \\
\hline Charisma $207 \mathrm{EC}$ & famoxate + flusilazole & $\begin{array}{l}\text { oxazolidines } \\
+ \text { triazoles }\end{array}$ & 1,5 & $\begin{array}{l}\text { Sikora i wsp. (2007) } \\
\text { Narkiewicz-Jodko i wsp. (2008) }\end{array}$ \\
\hline Artea $330 \mathrm{EC}$ & propiconazole + cyproconazole & $\begin{array}{l}\text { triazoles } \\
+ \text { triazoles }\end{array}$ & 0,5 & Sikora i wsp. (2007) \\
\hline Tango Star 334 SE & fenpropimorph + epoxiconazole & $\begin{array}{l}\text { morpholines } \\
+ \text { triazoles }\end{array}$ & 1,0 & $\begin{array}{l}\text { Sikora i wsp. (2007) } \\
\text { Narkiewicz-Jodko i wsp. (2008) }\end{array}$ \\
\hline Tilt Plus 400 EC & propiconazole + fenpropidin & $\begin{array}{l}\text { triazoles } \\
+ \text { morpholines }\end{array}$ & 1,0 & Narkiewicz-Jodko i wsp. (2008) \\
\hline Rex $500 \mathrm{SC}$ & thiophanate-methyl + epoxiconazole & $\begin{array}{l}\text { benzimidazoles } \\
+ \text { triazoles }\end{array}$ & 0,6 & Narkiewicz-Jodko i wsp. (2008) \\
\hline $\begin{array}{l}\text { Unix } 75 \mathrm{WG}+ \\
\text { Acanto } 250 \mathrm{EC}\end{array}$ & cyprodinil + picoxistrobin & $\begin{array}{l}\text { anilinopirimidin } \\
+ \text { strobilurin }\end{array}$ & $0,5+0,5$ & Narkiewicz-Jodko i wsp. (2008) \\
\hline $\begin{array}{l}\text { Jau } 64768 \& \text { Hecs } \\
5125\end{array}$ & propiconazole + fluoxastrobin & $\begin{array}{l}\text { triazoles } \\
+ \text { strobilurin }\end{array}$ & 1,25 & Narkiewicz-Jodko i wsp. (2008) \\
\hline Juwel TT 483 SE & $\begin{array}{l}\text { epoxiconazole }+ \text { fenpropimorph } \\
+ \text { kresoxim-methyl }\end{array}$ & $\begin{array}{l}\text { triazoles } \\
+ \text { morpholines } \\
+ \text { strobilurin }\end{array}$ & 1,2 & Narkiewicz-Jodko i wsp. (2008) \\
\hline BAS $52900 \mathrm{~F}$ & $\begin{array}{l}\text { fenpropimorph }+ \text { epoxiconazole } \\
+ \text { pyraclostrobin }\end{array}$ & $\begin{array}{l}\text { triazoles } \\
+ \text { triazoles } \\
+ \text { strobilurin }\end{array}$ & 1,5 & Narkiewicz-Jodko i wsp. (2008) \\
\hline
\end{tabular}

\section{Biofungicydy zawierające substancje naturalne pochodzenia roślinnego / Biofungicides containing natural substances of plant origin}

Powszechne stosowanie pestycydów może stwarzać zagrożenie dla środowiska, dlatego wzrasta zainteresowanie naturalnymi pestycydami. Taką alternatywą mogą stać się olejki eteryczne wyekstrahowane z roślin a wykazujące szereg cennych właściwości biologicznych, w tym działanie: przeciwbakteryjne, przeciwgrzybiczne i owadobójcze (Surviliene i wsp. 2009).

Te mieszaniny różnych związków, głównie: monoterpenów, monoterpenoidów, seskwiterpenów oraz substancji zapachowych (estry, ketony, fenole, alkohole, aldehydy, etery, węglowodory, kumaryny oraz kwasy organiczne) wykazują działanie grzybobójcze. Skutecznie ograniczają rozwój fitopatogennych grzybów rodzajów: Fusarium (F. oxysporum, F. culmorum) oraz Phytophthora, Stemphylium, Sphaerotheca, Botrytis, Erysiphe, Aspergillus, Mortierella, Sclerotinia, Sporotrichum, Penicillium i Alternaria w zakresie od 46 do 100\% (Klimach i wsp. 1996;
Orlikowski 2003; Burgieł i Smagłowski 2008; Surviliene i wsp. 2009). Ponieważ biobójcze działanie uzależnione jest od składu chemicznego i stężenia olejków oraz wrażliwości fitopatogennych szczepów grzybów, stale prowadzone są badania w kierunku wykorzystania olejków jako skutecznych biofungicydów (tab. 2).

Z badań przeprowadzonych przez Burgieła i Smagłowskiego (2008) wynika, że olejek z drzewa herbacianego w stężeniu $0,5 \%$ skutecznie hamował wzrost grzybów F. culmorum, Botrytis cinerea i Erysiphe sp. Grzybobójcze działanie tego olejku w stężeniach niższych $(0,1 ; 0,01$; $0,001 \%$ ) było znacznie słabsze i widoczne tylko w początkowym okresie doświadczenia, np. olejek w stężeniu $0,1 \%$ tylko częściowo ograniczał rozwój grzybni $F$. culmorum, zarówno in vitro, jak i in vivo oraz miał niewielki wpływ na cechy morfologiczne (Burgieł i Smagłowski 2008). Skuteczność grzybobójczą tego olejku potwierdzono w doświadczeniu poletkowym do ograniczania rozwoju Erysiphe sp. (mączniak prawdziwy) na nagietkach. Rośliny opryskiwane $0,5 \%$ roztworem olejku były w mniejszym stopniu porażone niż kontrolne. Skuteczność 
Tabela 2. Olejki eteryczne oceniane pod kątem zastosowania w biologicznej ochronie roślin (Klimach i wsp. 1996; Orlikowski 2003; Burgieł i Smagłowski 2008; Surviliene i wsp. 2009)

Table 2. Essential oils evaluated for their use in biological plants protection (Klimach et al. 1996; Orlikowski 2003; Burgieł and Smagłowski 2008; Surviliene et al. 2009)

\begin{tabular}{l|l}
\hline \multicolumn{1}{c|}{ Olejek etryczny - Essential oils } & \multicolumn{1}{c}{ Zastosowane stężenie - Used concentration } \\
\hline Olejek z drzewa herbacianego - Tea tree oil & 0,$001 ; 0,01 ; 0,1 ; 0,5 ; 1,0 ; 2,0 \%(\mathrm{v} / \mathrm{v})$ \\
\hline $\begin{array}{l}\text { Eukaliptusowy, z jodły syberyjskiej, ze świerku pospolitego, rozmarynowy } \\
\text { Eucalyptus oil, siberian fir oil, spruce oil, rosemary oil }\end{array}$ & 0,$005 ; 0,01 ; 0,015 \mathrm{ml}$ \\
\hline Ekstrakt z grejpfruta - Grapefruit extract & $165 ; 330 \mu \mathrm{g} / \mathrm{cm}^{3}$ \\
\hline Jałowcowy - Juniper berry oil & 0,$5 ; 1,0 ; 2,0 \%$ \\
\hline $\begin{array}{l}\text { Kminkowy, mietowy, tymiankowy } \\
\text { Caraway oil, peppermint oil, thyme oil }\end{array}$ & 0,$05 ; 0,1 ; 0,2 ; 0,25 ; 0,5 ; 1,0 ; 2,0 \%$ \\
\hline Tujowy - Thuja oil & 2,$0 ; 3,0 ; 4,0 \%$ \\
\hline
\end{tabular}

olejku z drzewa herbacianego (w stężeniu 0,5\%) potwierdziła w swoich badaniach Garbusińska i wsp. (2010, 2011).

Klimach i wsp. (1996) wskazali na możliwość zastosowania w ochronie roślin olejków: miętowego, kminkowego i tymiankowego, cechujących się podobną aktywnością grzybobójczą, jak środki chemiczne: zaprawa Funaben $\mathrm{T}$ i Ridomil $25 \mathrm{WP}$; w obecności olejków miętowego i kminkowego stosowanych w stężeniu $0,2 \%$ oraz tymiankowego $\mathrm{w}$ stężeniach 0,$05 ; 0,1$ i $0,2 \%$ obserwowano całkowite zahamowanie wzrostu grzyba F. sulphureum. Olejki te podobnie działały na grzyby Pythium spp.

Grzyby rodzaju Fusarium, np. F. catenulata, są także wrażliwe na lotne frakcje olejku rozmarynowego i tujowego (Surviliene i wsp. 2008).

Dużą uwagę zwraca się na skuteczność ekstraktu z grejpfruta (EG) w hamowaniu rozwoju fitopatogenów. Orlikowski (2003, 2001) wykazał, że ekstrakt ten jest skuteczny w stosunku do dwóch szczepów rodzaju Phytophora (P. ramorum i P. cryptoge), a efekt jego działania polega na hamowaniu wzrostu i tworzeniu przetrwalników patogena. Rozpad grzybni i deformacje zoosporangiów prowadzące do zahamowania rozwoju grzybów w podłożu obserwowano, gdy ekstrakt zastosowano w stężeniach 165 i $200 \mu \mathrm{g} / \mathrm{cm}^{3}$. Badania zależności między stężeniem ekstraktu $\mathrm{z}$ grejpfruta, a przetrwalnikami $P$. ramorum wykazały, że olejek w dawkach 8 i $40 \mu \mathrm{g} / \mathrm{cm}^{3}$ stymulował formowanie się chlamydospor, a w stężeniach wyższych (do $200 \mu \mathrm{g} / \mathrm{cm}^{3}$ ) całkowicie hamował tworzenie form przetrwalnych patogena (Orlikowski 2003). Fungistatyczne właściwości ekstraktu $\mathrm{Z}$ grejpfruta (w stężeniach 165 i $330 \mu \mathrm{g} / \mathrm{cm}^{3}$ ) w ochronie różanecznika przed $P$. ramorum potwierdzono w badaniach poletkowych. Zaobserwowano, że EG silnie hamował rozwój uszkodzeń (martwicy) chronionych liści różanecznika (Orlikowski 2003).

Podjęto także próby zastosowania olejku tymiankowego w ochronie róż przed Diplocarpon rosae, Sphaerotheca pannosa var. rosae (czarną plamistością) i Erysiphe spp. (mączniakiem prawdziwym) (Wagner i Spasówka 2007) oraz papryki przed chorobotwórczymi grzybami występującymi w warunkach polowych. Po zastosowaniu olejków obserwowano wzrost liczby grzybów saprobiotycznych rodzaju Trichoderma i Mucor na korzeniach papryki, co równocześnie prowadziło do ograniczenia liczebności grzybów chorobotwórczych (Jamiołowska i Wagner 2007).

Najniższą aktywność grzybobójczą wykazywały olejki z jodły syberyjskiej i ze świerku pospolitego, które tylko w nieznacznym stopniu hamowały rozwój patogenów (Surviliene i wsp. 2008).

Olejki o najsilniejszych właściwościach grzybobójczych znalazły zastosowanie w biologicznej ochronie roślin jako naturalne pestycydy, wykorzystywane głównie w rolnictwie ekologicznym lub stanowiące składniki biopreparatów. Do takich biopreparatów handlowych należą: Biosept 33 SL (Cintamani Polska) zawierający ekstrakt z grejpfruta; Timorex Gold (Biomor Israel Ltd.) - olejek z drzewa herbacianeg; Biochikol 020 PC (Gumitex PoliFarm) - chitozan - poli[ß-/1,4/-2amino-2deoxy-D-glukopiraoza]; Bioczos BR (Himal) zawierający wyciąg z czosnku. Cechuje je wysoka skuteczność i szerokie spektrum działania na patogeny.

Preparat Biosept 33 SL był skuteczniejszy i wykazywał długotrwałe działanie hamujące rozwój izolatów grzybów występujących na cukinii ( $F$. avenaceum, $F$. culmorum, $F$. equiseti, F. oxysporum, Alternaria alternata, B. cinerea, Rhizoctonia solani, Trichoderma hamatum) niż azoksystrobina (Amistar 250 SC, Syngenta) (Jamiołowska 2011). Świerczyńska (2010) potwierdziła skuteczność zarówno środków: Biosept 33 SL, Biochikol 020 PC, jak i Bioczos BR w hamowaniu rozwoju grzybów rodzaju Fusarium, takich jak: $F$. avenaceum, $F$. culmorum, $F$. graminearum, $F$. oxysporum i $F$. poae. Skuteczność działania testowanych biofungicydów, oceniana w odniesieniu do działania fungicydu syntetycznego Alert 375 SC (kontrola), zależała od wrażliwości szczepu i zastosowanej dawki. Preparaty stosowano w trzech różnych dawkach: zalecanej, 5-krotnie większej i 5-krotnie mniejszej. W dawce zalecanej, rozwój testowanych grzybów (od 46 do 69\%), w porównaniu do kontroli, najskuteczniej hamował Bioczos BR. Preparaty Biochikol 020 PC i Biosept 33 SL cechowały się słabszym działaniem. W dawce 5-krotnie większej zdecydowanie najskuteczniej ograniczał przyrost grzybni Bioczos BR, który całkowicie zahamował wzrost kolonii 5 gatunków Fusarium ( $F$. avenaceum, F. culmorum, $F$. graminearum, $F$. oxysporum, $F$. poae) i znacznie osłabił wzrost $F$. oxysporum $(87,5 \%)$. Również silną toksyczność w stosunku do badanych grzybów wykazał Biosept 33 SL, hamując wzrost kolonii od 60,3 do 82,1\% 
(Świerczyńska 2010). Bioczos BR i Biosept 33 SL in vitro zahamowały także rozwój grzybów gatunku Beauveria basiana i Paecilomyces fumosoroseus (Gorczyca 2007).

Rozwój grzybów gatunku $F$. oxysporum skutecznie ograniczał także biopreparat Timorex Gold. Charakteryzuje się on także szerokim spektrum grzybobójczym w stosunku do innych grup grzybów (Didymella bryoniae, Trichoderma spp., Sclerotium rolfsii i Thielaviopsis basicola) (Barbiel 2008).

Substancje czynne zawarte w wyciagach pochodzenia roślinnego wykazują nie tylko działanie grzybobójcze, ale wpływają także na żywotność i zdrowotność nasion. SasPiotrowska i Piotrowski (2010) wykazali istotne zróżnicowanie w działaniu 39 wyciagów roślinnych na żywotność i zdrowotność nasion jęczmienia. Działanie wyciagów zależało od: pochodzenia, rodzaju rośliny zielarskiej i sposobu przygotowania. Energię kiełkowania nasion najsilniej stymulowały wyciagi $\mathrm{z}$ owoców Coriandrum sativum, nasion Linum usitatissimum, korzeni Arctium lappa, kwiatów Verbascum thapsiforme, Levisticum officinalie, Marrubium vulgare i Lavendula vera.

Niektóre biopreparaty znalazły już zastosowanie praktyczne w sadownictwie (Sapieha-Waszkiewicz i wsp. 2005; Zydlik 2008). Trudno natomiast wskazać na prak- tyczne wykorzystanie biofungicydów w uprawach polowych, a w szczególności zbóż. Są to działania przyszłościowe i będą stanowiły element zintegrowanej ochrony środowiska.

\section{Biofungicydy zawierające mikroorganizmy antagonistyczne / Biofungicides containing antagonistic microorganisms}

W ochronie zbóż przed grzybami rodzaju Fusarium oprócz środków zawierających substancje naturalne pochodzenia roślinnego, stosowane są biopreparaty zawierające żywe mikroorganizmy i ich metabolity (Matyjaszczyk i Sobczak 2011). Wykorzystanie mikroorganizmów w biologicznej ochronie wiąże się ze zjawiskami: nadpasożytnictwa, konkurencji i antagonizmu. Jednym z ważniejszych, najczęściej badanych, bezpośrednich mechanizmów antagonizmu jest antybioza. Polega na wydzielaniu przez mikroorganizmy do środowiska przeciwgrzybowych substancji antybiotycznych i związków lotnych, enzymów litycznych i substancji indukujących odporność rośliny (gospodarza) czy substancji stymulujących wzrost roślin.

Tabela 3. Antygrzybowe substancje hamujące rozwój grzybów

Table 3. Antifungal substances inhibiting fungal growth

\begin{tabular}{|c|c|c|}
\hline Szczepy - Species & Substancje czynne - Biologically active substances & Literatura - Literature \\
\hline Trichoderma & $\begin{array}{l}\text { trichodermina virydyna, gliotoksyna, virydol, trichowirydyna, } \\
\text { trichotoksyna A i B } \\
\text { Antybiotyk V-21, trichoharzianina, peptaibole, tricholomginy, enzymy } \\
\text { lityczne } \\
\text { Trichoderma viride, gliotoxin, virydol, trichoviride, trichotoxin A i B } \\
\text { Antybiotic V-21, trichoharzianin, peptaibols, tricholomginy, lytic } \\
\text { enzymes }\end{array}$ & Brian i Hemming (2008) \\
\hline Gliocladium & $\begin{array}{l}\text { gliovirydyna, gliotoksyna, virydyna, } \\
\text { dehydrogliotoksyna, tiometylogliotoksyna, enzymy lityczne } \\
\text { glioviride, gliotoxin viride, dehydrogliotoxin, tiomethylogliotoxin } \\
\text { lytic enzymes }\end{array}$ & Lisboa i wsp. (2007) \\
\hline Bacillus & $\begin{array}{l}\text { bacillomycyna, eumycyna, fengymycyna, ituryna, selenomycyna } \\
\text { bacillomycinum, eumycinum, fengymycinum, iturin, selenomycinum }\end{array}$ & $\begin{array}{l}\text { Wang i wsp. (2007) } \\
\text { Akhtar i wsp. (2010) }\end{array}$ \\
\hline Pseudomonas & $\begin{array}{l}\text { hemipiocjanina, pioluteoryna, Pyrrolonitryna, siderofory helatujące } \\
\text { jon Fe(III) enzymy lityczne } \\
\text { hemipiocyanin, pioluteoryna, Pyrrolonitrin, Siderophores chelating } \\
\text { ion Fe (III) lytic enzymes }\end{array}$ & Akhtar i wsp. (2010) \\
\hline Azotobacter & $\begin{array}{l}\text { termolabilne antygrzybowe substancje } \\
\text { thermolabile antifungal substances }\end{array}$ & Chetverikov i Loginov (2009) \\
\hline Erwinia herbicola & herbicolacyna - herbicolacyna & Tenning i wsp. (1993) \\
\hline Streptomyces & $\begin{array}{l}\text { aktynomycyna, aktidion, polifungina, enzymy lityczne, kandycydyny } \\
\text { aktynomycinum, aktidion, polifungin, lytic enzymes, candicidins }\end{array}$ & Soares i wsp. (2009) \\
\hline Saccharomyces unispora & $\begin{array}{l}\text { antybiotyki i enzymy degradujące ścianę komórkową fitopatogena } \\
\text { antibiotics and enzymes degrading phytopathogen's cell wall }\end{array}$ & $\begin{array}{l}\text { El-Tarabily i Sivasithamparamb } \\
(2006)\end{array}$ \\
\hline S. cerevisiae 23 & enzymy lityczne - lytic enzymes & Santos i Marquina (2004) \\
\hline Candida steatolytica & $\begin{array}{l}\text { antybiotyki i enzymy lityczne } \\
\text { antibiotics and lytic enzymes }\end{array}$ & $\begin{array}{l}\text { El-Tarabily i Sivasithamparamb } \\
(2006)\end{array}$ \\
\hline $\begin{array}{l}\text { Pichia } \\
\text { P. anomala } \\
\text { P. membranefaciens }\end{array}$ & enzymy lityczne - lytic enzymes & Santos i Marquina (2004) \\
\hline
\end{tabular}


Tabela 4. Biopreparaty stosowane w ochronie roślin przed fitopatogennymi grzybami rodzaju Fusarium

Table 4. Bioproducts used in plant protection against phytopathogenic fungi from genus Fusarium

\begin{tabular}{|c|c|c|c|}
\hline $\begin{array}{c}\text { Nazwa handlowa biopreparatu } \\
\text { Commercial name } \\
\text { of the bioproduct }\end{array}$ & $\begin{array}{l}\text { Kraj } \\
\text { Country }\end{array}$ & $\begin{array}{l}\text { Szczepy mikroorganizmów } \\
\text { Strains of microorganisms }\end{array}$ & $\begin{array}{l}\text { Rodzaj uprawy } \\
\text { Crop type }\end{array}$ \\
\hline Bio-Fungus & $\begin{array}{l}\text { Belgia } \\
\text { Belgium }\end{array}$ & \multirow{6}{*}{ Trichoderma harzianum } & \multirow{13}{*}{$\begin{array}{l}\text { uprawy polowe } \\
\text { i pod osłonami, } \\
\text { produkcja rozsady } \\
\text { (warzyw, drzew owocowych } \\
\text { i roślin ozdobnych) } \\
\text { field crops and } \\
\text { greenhouse-grown, } \\
\text { production of seedlings } \\
\text { (vegetables, fruit trees } \\
\text { and ornamental plants) }\end{array}$} \\
\hline $\begin{array}{l}\text { Trichoderma } 2000 \\
\text { Trichodex }\end{array}$ & $\begin{array}{l}\text { Izrael } \\
\text { Israel }\end{array}$ & & \\
\hline Supresiwit & $\begin{array}{l}\text { Czechy } \\
\text { Czech Republic }\end{array}$ & & \\
\hline RootShield & \multirow{4}{*}{$\begin{array}{l}\text { USA } \\
\text { The USA }\end{array}$} & & \\
\hline Bio-Treck & & & \\
\hline Planter BoX & & & \\
\hline SoilGard & & T. virens & \\
\hline Binab $\mathrm{T}$ & $\begin{array}{l}\text { USA } \\
\text { i Szwecja } \\
\text { The USA } \\
\text { and Sweden }\end{array}$ & $\begin{array}{l}\text { T. harzianum } \\
\text { T. polysporum }\end{array}$ & \\
\hline Trichoderm & $\begin{array}{l}\text { Polska } \\
\text { Poland }\end{array}$ & T. viride & \\
\hline Trichopel, Trichoject & $\begin{array}{l}\text { Nowa Zelandia } \\
\text { New Zealand }\end{array}$ & $\begin{array}{l}\text { T. harzianum } \\
\text { T. viride }\end{array}$ & \\
\hline Mycostop & $\begin{array}{l}\text { Finlandia } \\
\text { Finland }\end{array}$ & Streptomyces spp. & \\
\hline Candifruit & $\begin{array}{l}\text { Hiszpania } \\
\text { Spain }\end{array}$ & Candida sake & \\
\hline Polyversum WP & $\begin{array}{l}\text { Polska } \\
\text { Poland }\end{array}$ & Pythium oligandrum & \\
\hline
\end{tabular}

Zdolność do produkcji substancji antybiotycznych jest powszechna dla $50 \%$ grzybów, promieniowców i bakterii glebowych (tab. 3). Takie zjawisko może wystąpić w fyllosferze i ryzosferze roślin oraz przy kiełkujących nasionach lub ziarniakach, gdzie następuje stały dopływ związków pokarmowych (Kurek i Kobus 1990; Pięta 1997). W ostatnich latach uwage zwraca się na możliwość wykorzystania w ochronie roślin także drożdży rizosferowych (Santos i wsp. 2004; El-Tarabily i wsp. 2006).

Skuteczne działanie w biologicznej ochronie jest zazwyczaj efektem występowania kilku mechanizmów jednocześnie, zazwyczaj: wytwarzania substancji antybiotycznych, enzymów litycznych nadpasożytnictwa i konkurencji. Aktywność lityczną, m.in. w stosunku do grzybów rodzaju Fusarium wykazują promieniowce (Streptomyces, Nocardia) i bakterie oraz grzyby rodzajów Trichoderma i Gliocladium, a także drożdże. Wytwarzane enzymy, takie jak: chitynaza, celulaza, amylaza i laminarynaza ( $\beta-1-3$ glukanaza), rozpuszczają ścianę komórek grzybni wegetatywnej przetrwalnikowej i zarodników fitopatogena.

Ważną rolę, czynnika biologicznego ograniczającego rozwój patogenów roślinnych, spełniają antagonistyczne grzyby rodzaju Trichoderma: T. harzianum, T. pseudokoningii i $T$. viride. Hamują rozwój pasożytniczych grzybów glebowych powodujących zgorzele siewek, gnicie korzeni oraz więdnięcie prowadzące do zamierania roślin. Jednak ze względu na fakt, że niska temperatura $\left(5-15^{\circ} \mathrm{C}\right)$ oto- czenia obniża tempo wzrostu grzybni Trichoderma spp., ich aktywność w hamowaniu rozwoju fitopatogenów takich, jak: B. cinerea, $F$. solani czy $R$. solani jest niska (Dłużniewska 2004). Biopreparaty oparte na Trichoderma spp. (tab. 4) mają większe perspektywy stosowania w uprawach szklarniowych lub pod osłonami niż w warunkach polowych. Biopreparaty mogą być wykorzystywane $\mathrm{w}$ ochronie roślin zarówno do zaprawiania materiału siewnego, opryskiwania upraw czy indukowania odporności roślin.

Skutecznym środkiem biokontroli w uprawach są także inne grzyby, np. Pythium oligandrum, który kolonizuje korzenie bez uszkadzania komórek roślinnych, przeżywa w ryzosferze, stymuluje reakcje obronne roślin i promuje ich wzrost eliminując przy tym grzyby chorobotwórcze, m.in. P. dissotocum (Vallance i wsp. 2009). Zadawalajace efekty uzyskano po zastosowaniu preparatu Poliversum WP (tab. 4) w uprawach pomidorów.

Bardzo istotnym aspektem biologicznej ochrony jest także wspomaganie wzrostu roślin, przez drobnoustroje rizosferowe, tzw. PGP (Plant Growth Promoting), m.in. przez produkcję: fitohormonów (auksyn, giberelin i cytokinin), witamin, sideroforów czy zwiększenie dostępności azotu i fosforu. Zdolność do wytwarzania substancji typu regulatorów wzrostu roślin wykazano dla promieniowców Streptomyces antagonistycznych, w stosunku do fitopatogenów $-F$. culmorum i $F$. avenaceum (Krzyśko-Łupicka 2011). 


\section{Podsumowanie / Summation}

Środki ochrony roślin pochodzenia naturalnego dostępne w Polsce stanowią jedynie 5\% ogółu środków dopuszczonych do obrotu i rejestracja kolejnych byłaby niezwykle przydatna, szczególnie w obliczu wprowadzenia integrowanej ochrony roślin (Matyjaszczyk i Sobczak 2011). Poszukiwanie alternatywnych rozwiązań w zwalczaniu fitopatogenów roślin przyczyni się do lepszej ochrony środowiska przed skażeniami chemicznymi, co zapewni różnorodność biologiczną i ochronę zasobów naturalnych. Ponadto eliminacja groźnych patogenów za pomocą biofungicydów pozwoli na uzyskanie zwiększonych plonów o wysokiej zdrowotności, co umożliwi zaspokojenie rosnącego zapotrzebowania na zboże (Suchorzyńska i Misiewicz 2009; Krzemiński 2011) i zachęci do stosowania naturalnych metod ochrony roślin $\mathrm{w}$ walce $\mathrm{z}$ fitopatogenami.

\section{Literatura / References}

Akhtar M.S., Shakell U., Siddiqui Z.A. 2010. Biocontrol of Fusarium wilt by Bacillus pumilus, Pseudomonas alcaligenes, and Rhizobium sp. on lentil. Tübitak 34: 1-7.

Barbier M. 2012. In vitro sensitivity of Didymella bryoniae, Fusarium oxysporum, Trichoderma spp., Sclerotium rolfsii and Thielaviopsis basicola to the botanical fungicide Timorex Gold (Melaleuca alternifolia) under the "Paper disk diffusion" and the "Poisoning agar" testing methods. University of Florida-IFAS. Plant Medicine Program, Gainesville, FL. 32611, 20 pp. (Published by Marcel Barbier on Mar 20, 2012), http://pl.scribd.com/doc/86131901/In-Vitro-Sensitivity-to-Timorex-Gold-of-Five-DifferentFungi-Under-Two-Different-Methods

Brian P.W., Hemming H.G. 2008. Gliotoxin, a fungistatic metabolic product of Trichoderma viride. http://onlinelibrary.wiley.com/doi/ 10.1111/j.1744-7348.1945.tb06238.x/abstract [Accessed: 26.02.2008].

Burgieł Z.J., Smagłowski M. 2008. Fungistyczne własności olejku z drzewa herbacianego. Zesz. Probl. Post. Nauk Rol. 529: 13-18.

Chetverikov S.P., Loginov O.N. 2009. New metabolites of Azotobacter vinelandii exhibiting antifungal activity. Microbiology 78 (4): $428-432$.

Dłużniewska J. 2004. Wpływ temperatury inkubacji na rozwój i stosunki biotyczne między Trichoderma spp. a grzybami patogenicznymi. Acta Sci. Pol. Agricul. 3 (2): 257-262.

El-Tarabilya K.A., Sivasithamparamb K. 2006. Non-streptomycete actinomycetes as biocontrol agents of soil-borne fungal plant pathogens and as plant growth promoters. Soil Biol. Biochem. 38: 1505-1520.

Garbusińska A., Mertas A., Król W. 2010. Przegląd badań in vitro oceniających aktywność przeciwdrobnoustrojową olejku z drzewa herbacianego (Tea Tree Oil). Cz. I. Borgis - Post. Fitoterapii 2: 85-96.

Garbusińska A., Mertas A., Szliszka E., Król W. 2011. Aktywność przeciwdrobnoustrojowa olejku z drzewa herbacianego (Tea Tree Oil) w badaniach in vitro. Cz. II. Borgis - Post. Fitoterapii 3: 175-184.

Gorczyca A. 2007. Wpływ środków Biosept 33 SL i Bioczos BR na wybrane grzyby owadobójcze in vitro. [The effect of preparations Biosept $33 \mathrm{SL}$ and Bioczos BR on selected enthomopathogenic fungus in vitro]. Prog. Plant Prot./Post. Ochr. Roślin 47 (4): $142-144$.

Jamiołkowska A., Wagner A. 2007. Próby zastosowania olejku tymiankowego do ochrony papryki uprawnej w polu przed grzybami chorobotwórczymi. [Effect of thyme oil in protection against fungal diseases on pepper grown in the field]. Prog. Plant Prot./Post. Ochr. Roślin 47 (4): 149-153.

Jamiołkowska A. 2011. Laboratory effect of azoxystrobin (Amistar 250 SC) and grapefruit extract (Biosept 33 SL) on growth of fungi colonizing zucchini plants. Acta Sci. Pol. 10 (2): 245-257.

Khan M.R., Fischer S., Egan D., Doohan F.M. 2006. Biological control of Fusarium seedling blight disease of wheat and barley. Phytopathology 96: 386-394.

Klimach A., Wieczorek W., Góra J. 1996. Wpływ olejków eterycznych na ograniczenie występowania niektórych chorób grzybowych i bakteryjnych roślin. Pestycydy 1: 45-54.

Korbas M. 2005. Ochrona zbóż po ukazaniu się liścia flagowego. Ochrona Roślin 5: 29-32.

Korbas M., Horoszkiewicz-Janka J. 2007. Wpływ ochrony roślin na jakość plonu zbóż. Wieś Jutra 4 (105): $29-32$.

Kordowska-Wiater M. 2011. Drożdże jako czynniki ochrony biologicznej roślin. Post. Mikrobiol. 50 (2): 107-119.

Krzemiński M. 2011. Rośnie zapotrzebowanie na zboże. Agro Serwis 5: 11-13.

Krzyśko-Łupicka T. 1993a. Możliwości zastąpienia fungicydów szczepami drobnoustrojów saprofitycznych w zwalczaniu grzybów fitopatogennych (F. culmorum i F. avenaceum). Ekol. Rol.: 55-58.

Krzyśko-Łupicka T. 1993b. Poszukiwanie wzajemnych zależności między drobnoustrojami saprofitycznymi i fitopatogenami w celu stworzenia podstaw biologicznego ich zwalczania. Praca doktorska. Akademia Rolnicza, Wrocław, 89 ss.

Krzyśko-Łupicka T. 2010. Some aspects of antagonistic bacteria strains application o control wheat fusariosis. Proc. ECOpole 4 (2): 433-438.

Krzyśko-Łupicka T. 2011. Wykorzystanie antagonistycznych właściwości bakterii do zwalczania fuzariozy pszenicy. Chem. Dydakt. Ekol. Metrol. 16 (1-2): 51-55.

Krzyśko-Łupicka T., Sudoł T. 2005. The ability of selected Fusarium fungi to a growth in the presence of different glyphosate concentrations. Pol. J. Chem. Technol. 7 (2): 10-15.

Krzyśko-Łupicka T., Sudoł T. 2008. Interactions between glyphosate and autochthonous fungi surviving in aqueous solution of glyphosate. Chemosphere 71: 1386-1391.

Kurek E., Kobus J. 1990. Korzystne i szkodliwe oddziaływanie mikroflory ryzosferowej na wzrost i rozwój roślin. Post. Mikrobiol. 29, $1(2): 103-124$

Kwaśna H., Chełkowski J., Zajkowski P. 1991. Grzyby. Polska Akademia Nauk, Warszawa-Kraków, 152 ss. 
Lisboa B.B., Bochese C.C., Vargas L.K., Silveira J.R.P., Radin B., Rota de Oliveira A.M. 2007. Efficiency of Trichoderma harzianum and Gliocladium viride in decreasing the incidence of Botrytis cinerea in tomato cultivated in protected environment. Ciência Rural 37 (5): 1255-1260.

Małecka I., Blecharczyk A., Sawińska Z. 2001. Wpływ systemu uprawy roli na występowanie chorób w pszenżycie ozimym i jęczmieniu jarym. [The influence of tillage systems on disease occurence in winter triticale and spring barley]. Prog. Plant Prot./Post. Ochr. Roślin 41 (2): 920-923.

Matyjaszczyk E., Sobczak J. 2011. Środki ochrony roślin zawierające substancje aktywne pochodzenia naturalnego. Bydgoskie Towarzystwo Naukowe: 307-310.

Narkiewicz-Jodko M., Gil Z., Urban M. 2005. Porażenie podstawy źdźbła pszenicy ozimej przez Fusarium spp. - przyczyny i skutki. Acta Agrobot. 58 (2): 319-328.

Narkiewicz-Jodko M., Mularczyk A., Urban M. 2008. Wpływ fungicydów na jakość i zdrowotność ziarna jęczmienia jarego. [The influence of fungicides on quality and health of spring barley grain]. Prog. Plant Prot./Post. Ochr. Roślin 48 (1): 237-245.

Nowak W., Sowiński J., Pietr S.J., Kita W. 2005. Wpływ sposobów ochrony pszenicy ozimej na jakość ziarna konsumpcyjnego. Pam. Puł. 139: 117-127.

Orlikowski L.B. 2001. Effect of grapefruit extract on development of Phytophthora cryptogea and control of foot rot of gerbera. J. Plant Prot. Res. 41 (3): 288-294.

Orlikowski L.B. 2003. Development and spread of Phytophthora ramorum in the presence of grapefruit extract. J. Plant Prot. Res. 43 (3): 213-218.

Orlikowski L.B. 2011. Effect of grapefruit extract on development of Phytophthora cryptogea and control of foot rot of gerbera. J. Plant Prot. Res. 41 (3): 288-294.

Pięta D. 1997. Niektóre aspekty wykorzystania mikroorganizmów antagonistycznych do zwalczania chorób roślin. Ann. Univ. Mariae Curie-Skłodowska, Sect. EEE, Horticultura 5: 1-8.

Różalski K., Blecharczyk A., Skrzypczak G., Piechota T. 1998. Choroby podsuszkowe pszenicy ozimej uprawianej po różnych przedplonach w systemie siewu bezpośredniego. [Stem base disease incidence on direct seeded winter wheat after different previous crops]. Prog. Plant Prot./Post. Ochr. Roślin 38 (2): 555-557.

Santos A., Marquina D. 2004. Killer toxin of Pichia membranifaciens and its possible use as a biocontrol agent against grey mould disease of grapevine. Microbiology 150: 2527-2534.

Sapieha-Waszkiewicz A., Marjańska-Cichoń B., Miętkiewski R., Żurek M. 2005. Reakcja grzybów owadobójczych na fungicydy pochodzenia roślinnego i syntetycznego in vitro. Acta Agrobot. 58 (1): 101-111.

Sas-Piotrowska B., Piotrowski W. 2010. Vitality and healthiness of barley (Hordeum vulgare L.) seeds treated with plant extracts. J. Plant Prot. Res. 50 (1): 117-124.

Sikora H., Banachowska J., Doleżych D. 2007. Badania nad ochroną pszenicy ozimej przed fuzariozą kłosów wywołaną przez Fusarium culmorum w warunkach sztucznej infekcji. [Studies on chemical protection of winter wheat against Fusarium head blight caused by Fusarium culmorum in conditions of artificial infection]. Prog. Plant Prot./Post. Ochr. Roślin 47 (2): 314-318.

Soares C.F., Sousa C., Garrido M. 2009. Streptomycetes antagonism against Cladosporium fulvum Cooke and Fusariumo xysporium lycopersici. Ciencia Rural 6: 1897-1900.

Sobiczewski P. 2010. Bakterie w ochronie roślin przed agrofagami - znaczenie gospodarcze i biotechnologia. [Bacteria in plant protection against agrophages - economic importance and biotechnology]. Prog. Plant Prot./Post. Ochr. Roślin 50 (3): $1064-1073$.

Suchorzyńska M., Misiewicz A. 2009. Mikotoksynotwórcze grzyby fitopatogeniczne z rodzaju Fusarium i ich wykrywanie technikami PCR. Post. Mikrobiol. 48 (3): 221-230.

Survilienė E., Valiuškaitė A., Snieškienė V., Stankevičienė A. 2009. Effect of essential oils on fungi isolated from apples and vegetables scientific works of the Lithuanian institute of horticulture and Lithuanian Univeristy of agriculture. Sodininkyste ir Darzininkyste 28 (3): $228-234$.

Świerczyńska I. 2010. Wpływ wybranych biopreparatów na wzrost kilku gatunków grzybów z rodzaju Fusarium w warunkach laboratoryjnych. J. Res. Appl. Agric. Engin. 55 (4): 158-161.

Tenning P., van Rijsbergen R., Zhao Y., Joos H. 1993. Cloning and transfer of genes for antifungal compounds from Erwinia herbicola to Escherichia coli. Mol. Plant-Microbe Interactions 6 (4): 474-480.

Vallance J., Le Floch G., Déniel F., Barbier G., Lévesque C.A., Rey P. 2009. Influence of Pythium oligandrum biocontrol on fungal and oomycete population dynamics in the rhizosphere. Appl. Environ. Microbiol. 75 (14): 4790-4800.

Wagner A., Spasówka M. 2007. Próby zastosowania Candida butyri i olejku tymiankowego w ochronie róży przed czarną plamistością i mączniakiem prawdziwym. [Research on Candida butyri and thyme essential oil applications in the control of black spot and powdery mildew on rose]. Prog. Plant Prot./ Post. Ochr. Roślin 47 (4): 251-254.

Wang J., Liu J., Chen H., Yao J. 2007. Characterization of Fusarium graminearum inhibitory lipopeptide from Bacillus subtilis. Appl. Microbiol. Cell Physiol. 76: 889-894.

Weber R. 2007. Zagrożenie i sposoby ograniczania chorób fuzaryjnych pszenicy. Post. Nauk Rol. 2: 19-31.

Zydlik P. 2008. Wykorzystanie preparatów pochodzenia naturalnego w zwalczaniu niektórych chorób roślin sadowniczych. Nauka Przyroda Technologie 2 (1): 1-6. 